\title{
THE RIGHT TO RELIGIOUS FREEDOM AND WORLD PUBLIC ORDER: THE EMERGING NORIM OF NONDISCRIMINATION ${ }^{\dagger}$
}

\author{
Myres $S$. McDougal* \\ Harold D. Lasswell** \\ Lung-chu Chen ****
}

\section{Factual Background}

D ISCRIMINATION based upon religious beliefs and expressions forms the basis for some of the most serious deprivations of civil and political rights. ${ }^{1}$ The religious beliefs and expressions that are commonly the ground for discrimination include all of the traditional faiths and justifications from which norms of responsible conductthat is, judgments about right and wrong-are derived. These beliefs may be theological in the sense that they refer to a personalized transempirical source of an unchallengeable message or metaphysical in the sense that they are grounded upon nonpersonalized transempirical conceptions; sometimes they are more empirical, based upon varying conceptions of science or fundamental humanity. ${ }^{2}$ Deprivations may be imposed upon an individual because he refuses to accept the established belief system, adheres to a belief system different from the established one, attempts to create a new set of beliefs, expresses doubt about existing belief systems, or explicitly challenges the valid-

$\dagger$ This article is excerpted from a book to be published, Human Rights and World Public Order. The authors acknowledge with thanks the criticism and comments of Professors W. Michael Reisman, Irving I. Zaretsky, and John Claydon. The Ralph E. Ogden Foundation has been generous in its support of the studies from which this article is drawn.

* Sterling Professor of Law, Emeritus, Yale Law School. B.C.L. 1930, Oxford University; J.S.D. 1931, Yale; LL.B. 1935, University of Mississippi.-Ed.

** Ford Foundation Professor of Law and Social Sciences, Emeritus, Yale Law School. Ph.B. 1922, Ph.D. 1926, University of Chicago.--Ed.

*** Senior Research Associate, Yale Law School. LL.B. 1958, National Taiwan University; LL.M. 1961, Northwestern University; LL.M. 1962, J.S.D. 1964, Yale University.-Ed.

1. See generally M. BATES, ReLigious LIBerty: AN INQUIRY (1945); A. KRISHNASWAMI, STUDY OF Discrimination IN tHE MATTER OF RELIGIOUS RIGHTS AND Practices, U.N. Doc. E/CN.4/Sub.2/200/Rev.1 (1960); P. LaNARÈs, LA Liberté Religieuse dans les Conventions Internationales et dans le Droit Public GÈnÈral (1964); Abram, Freedom of Thought, Conscience and Religion, $8 \mathrm{~J}$. INTL. COMMN. OF JuRIsTs, No. 2, at 40 (1967); Claydon, The Treaty Protection of Religious Rights: U.N. Draft Convention on the Elimination of All Forms of Intolerance and of Discrimination Based on Religion or Belief, 12 SANTA CLARA LAW. 403 (1972); Toth, Human Dignity and Freedom of Conscience, 10 WORLD Justice 202 (1968).

2. A recent outstanding survey of religious beliefs is RELIGIOus MOVEMENTS iN CONTEMPORARY AMERICA (I. Zaretsky \& M. Leone eds. 1974) Thereinafter Relrgrous Movements]. For a diversity of religious perspectives, see T. DoBzHANSKY, ThE 
ity of belief systems. ${ }^{3}$ The individual may be deprived of rights either through formal community decision-making processes or through less obvious workings of effective power. ${ }^{4}$

Religious discrimination looms large in the histories of most of the world's distinctive religions. The common theme of these histories (with different religions appearing alternatively as oppressors and as victims) has been that of persecution; toleration has developed only at relatively late stages. ${ }^{5}$ For a long time, the established mode by which many religions dealt with heretics or nonbelievers was short and quick. The ultimate deprivation was imposed upon those who failed to conform. ${ }^{6}$ In more recent times, though toleration has become widespread, religious discrimination still abounds and is the source of repressive measures that deny individuals the most basic of human freedoms. In the words of a United Nations study:

World-wide interest in ensuring the right to freedom of thought, conscience and religion stems from the realization that this right is of

Biology of Ultimate Concern (1967); M. Eliade, Patterns in Comparative Religion (R. Sheed transl. 1963); M. Eliade, The SaCred and the Profane (W. Trash transl. 1961); S. FreUd, The Future of aN Illusion (W. Robson-Scott transl. 1928); J. Hick, Philosophy of Religion (1963); W. KaufmanN, Critique of Religion and Philosophy (1958); W. Lessa \& E. Vogt, Reader in Comparattve Religion (3d ed. 1972); H. Lewis, Philosophy of Religion (1965); S. McCasLand, G. Cairns \& D. Yu, Religions of the World (1969); M. Mead, TWentieth Century FatTH: Hope and SuRvival 83-87 (1972); A. Montagu, Immortality, Religion, and Morals (1971); E. Parrinder, Comparative Religion (1962); N. Smart, The Religious Experience of Mankind (1969); J. Wach, The ComParattve Study of Religions (1961); M. Weber, THE Sociology of Religion (T. Parsons ed. 1963); J. Yinger, Religion, Society aNd THE INDIVIdUAL (1957); J. YINGER, THE SCIENTIFIC STUdY OF RELIGION (1970).

3. Thus, deprivees can include atheists and agnostics. See generally T. AlTIZER \& W. Hamilton, Radical Theology and the Death of God (1966); C. Campbell, Toward a Sociology of IrReligion (1971); W. Clifford, THe Ethics of Belief, AND Other Essays (1876); J. Dewey, A COMmon Faith (1934); R. Robinson, AN Atheist's Values (1964); G. Vahanian, The Death of God (1961).

4. Important deprivations may be imposed through the internal processes of religious groups themselves. Sometimes these deprivations have the tacit approval of government; upon occasion they become the functional equivalent of government. $C f$. Gerlach, Pentecostalism: Revolution or Counter-Revolution?, in Religious MoveMENTS, supra note 2, at 669-99; Kauper \& Ellis, Religious Corporations and the Law, 71 MICH. L. REV. 1499, 1557-74 (1973).

5. See H. Kamen, The Rise of Toleration (1967); Adeney, Toleration, 12 ENCYC. OF Religion AND Ethics 360 (J. Hastings ed. 1958). See also J. Bigelow, Toleration and Other Essays and Studies (1927); W. Garrison, Intolerance (1934); G. MENSChing, Tolerance and Truth in Religion (H. Klimkeit transl. 1971). In the words of Garrison:

History is made up very largely of the record of man's intolerance to man. Part of that record is red with the blood of its victims and vibrant with their groans. Part of it also is warm with the glow of the faith and zeal of those who have sought, at their own peril, to turn others from the error of their ways or to break down some system which they deemed hostile to the welfare of men. But the story of intolerance is also the story of all the world's prophets and saviours, its moral leaders and social reformers, as well as its tyrants and inquisitors.

W. GARRISON, supra, at $\mathrm{x}$.

6. See text at notes 28-38 infra. 
primary importance. In the past, its denial has led not only to untold misery, but also to persecutions directed against entire groups of people. Wars have been waged in the name of religion or belief, either with the aim of imposing upon the vanquished the faith of the victor or as a pretext for extending economic or political domination. Although the number of such instances occurring in the second half of our century is on the decline, it must not be forgotten that mankind only recently has witnessed persecutions on a more colossal scale than ever before. And even today, notwithstanding changes in the climate of opinion, equality of treatment is not ensured for all religions and beliefs, or for their followers, in certain areas of the world. ${ }^{7}$

The relevant deprivations imposed upon individuals invariably involve the rectitude value itself, denying participation in the formulation and expression of moral norms. Individuals may be denied, both in form and in substance, the freedom to worship as they choose; they may be terrorized from worshipping, or they may be brainwashed or coerced into following a belief system other than that of their own choosing (e.g., compulsory conversions). ${ }^{8}$ These types of repressive measures are particularly likely to occur in those communities in which an established belief system is officially sanctioned and sustained to the exclusion of other beliefs. ${ }^{9}$ History is full of examples

7. A. KRISHNaswami, supra note 1, at v. In the words of Claydon:

Even a cursory survey of matters considered by the United Nations in the past twenty-five years demonstrates the extent to which religious differences continue to contribute to major and minor problems of world order. Such a list might include the following items: religious persecution in Bulgaria, Hungary, and Rumania, 1949; the Kashmir dispute between India and Pakistan; the treatment of Buddhists in South Vietnam, 1963; the actions of the People's Republic of China in Tibet, 1959-61; the Cyprus problem; the continuing Middle East crisis; and the current situation in Northern Ireland. In all of these cases the religious factor has operated in varying degrees either to precipitate or to exacerbate an international crisis; in most violence has been a component.

Claydon, supra note 1 , at 403.

Useful contemporary area studies of the interaction of religion and politics include

R. Bush, Religion in Communist China (1970); J. Coquia, Church and State LaW IN the Philippines (1959); G. MacEotn, Northern Ireland: Captive of History 123-44 (1974); D. Macinnis, Religious Policy aNd PRACTICE IN CoMmunist China (1972); Religion, Politics, and Social Change in the Third Worid (D. Smith ed. 1971); D. SchMeIser, Crvil LIBERTIEs IN CaNada 54-124 (1964); South Astan Politics ANd Religion (D. Smith ed. 1966).

8. See, e.g., Arnold, Persecution (Muhammadan), 9 ENCYc. OF Religion aNd ETHICs 765, 767 (J. Hastings ed. 1960). Similar treatment is reported to occur in the Soviet Union. See V. Chalddze, To Defend These Rights: Human Rights and the Soviet Union 159 (G. Daniels transl. 1974). Cf. H. SMIth, The Russians 417-38 (1976); Jancar, Religious Dissent in the Soviet Union, in DISSENT IN THE USSR: Politics, Ideology, aNd People 191 (R. Tökés ed. 1975); Reddaway, Freedom of Worship and the Law, in IN QUEST of Justice: Protest AND Dissent IN THE SovieT UNION TODAY 62 (1970).

9. See, e.g., Roman Catholicism, History of, 15 ENCYC. BRTr. 1002, 1006-07 (15th ed. 1974).

Underscoring the central importance of "religious persecution" to Marxism. Solzhenitsyn offers this footnote: "Sergei Bulgakov showed in Karl Marx as a Religious Type (1906) that atheism is the chief inspirational and emotional hub of Marxism and that all the rest of the doctrine has simply been tacked on. Ferocious 
of religious oppression through such means as the destruction of altars, images, churches, temples, and the holy scriptures. ${ }^{10}$

Deprivations of power on rectitude grounds are dramatized by the conflicts between church and state. ${ }^{11}$ The religiously persecuted have been forced to leave the community of which they were members and in consequence have been completely excluded from the power processes of the body politic. For many, the result has been centuries of wandering as homeless refugees and exiles in perpetual fear and jeopardy - a phenomenon that has yet to see an end. ${ }^{12}$ The barbarity of banishment is sometimes confined within national boundaries when the persecuted are dispatched to remote, sparsely populated, and rugged frontiers. ${ }^{13}$ Conversely, people may be denied egress, either temporarily or permanently, because of their relig-

hostility to religion is Marxism's most persistent feature." A. SolzHENTTSYN, LETTER To THE Soviet Leaders 58-59 (H. Sternberg transl. 1975). See also Bourdeaux, Religions in the Soviet Union (1960-71): Introduction, in THE FOURTH WoRLD: VICTIMS OF GROUP OPPRESSION 218, 222 (B. Whitaker ed. 1972); Shararevich, Socialism in Our Past and Future, in A. SOLZHENITSYN, et al., From UNDER THE RUBBLE 26 (M. Scammell, et al. transl. 1975).

In the People's Republic of China, the Religious Affairs Bureau came into existence in the early years of the regime. The functions of the Bureau include the following:

1. To regularly investigate and study religious organizations and the activities of their personnel.

2. To control all types of religious activity.

3. To lead both Catholics and Protestants into the Three-Self Movement, and to organize Buddhists, Taoists, and Muslims for regular patriotic learning sessions.

4. To carry out thoroughly the religious policy of the central government.

5. To unceasingly teach and propagandize religious leaders and all believers concerning policies of the state with respect to current situations in order to raise their political awareness.

6. To bring church leaders closer to the government and push believers of all religions into a positive alliance for the construction of socialism.

7. To strike at politically obstinate reactionaries in churches, and cooperate with public security officers in order to tranquilize hidden counterrevolutionaries in all religions.

8. To entertain foreign religious guests.

R. BuSH, supra note 7, at 31 (footnote omitted). See also D. MacINnis, supra noto 7, at 373; G. Patterson, Christianity in Communist China 3-4 (1969). Other works dealing with religion and communism include J. BENNETT, CHRISTIANITY AND Communism Today (1970); H. Chambre, Christianity and Communism (R. Trevett transl. 1960); M. D'ARCY, COMMUNISM AND Christianity (1957); A. Galter, The Red Book of the Persecuted Church (1957); G. Maceoin, The COMMUNIST WAR ON RELIGION (1951).

10. See, e.g., L. Dawidowicz, The War AganNst the Jews 1933-1945, at 248 (1975); J. Goff, The Persecution of Protestant Christians in Colombia, 19481958, at 4/35-4/45 (1968) (SONDEOS No. 23); Adeney, supra note 5, at 361; Gwatkin, Persecution (Early Church), 9 ENCYc. OF RELIGION AND ETHICs 742, 743, 747 (J. Hastings ed. 1960).

11. Cf. G. Lewy, Religion and Revolution (1974); S. Steinberg, The Thurty YeARS WAR AND THE CONFLICT FOR EUROPEAN HEgEMONY 1600-1660, at 96-99 (1966); C. WEDGWOOd, THE THIRTY YEARS WAR (1938).

12. For a comprehensive historical account, see F. NorwOod, Strangers AND EXILES: A HISTORY OF RELIGIOUS REFugeEs (1969).

13. Whitley, Persecution (Modern Christian), 9 ENCYC. OF Religion aNd ETHICs 755, 758 (J. Hastings ed. 1960). 
ious background, ${ }^{14}$ and nationals of centain religious faiths may be denied access to their own country. ${ }^{15}$ In some notorious inquisitions, the methods employed against nonconformists have been completely arbitrary, involving no less than a total denial of due process of law. ${ }^{16}$ Less drastically, holding or expressing particular religious beliefs may be made a criminal offense. ${ }^{17}$ The entire arsenal of criminal sanctions, including fine, imprisonment, banishment, and capital punishment, may be mobilized to enforce religious conformity. ${ }^{18}$ Another frequent deprivation is to forbid religious nonconformists to hold assemblies. ${ }^{19}$

An individual's rights to vote or to hold office may be affected by religious identification, even in communities with no established religion. "Where there is an Established Church or a State religion," according to a United Nations study, "persons who leave the officially recognized religion are sometimes deprived of their political rights, including the right to vote."20 Sometimes, "clerics of the official religion may be regarded as officials of the Government while those of other groups do not enjoy such a status."21 Eligibility for high governmental posts, including the head of state, may, "either by law or by tradition," be confined to those who hold the officially sanctioned religious beliefs. ${ }^{22}$ In communities where "several religions are officially recognized," discrimination may result from the use of "quota systems" in allocating "elective and appointive posts in the public service"; such systems may stress "community membership"

14. For a discussion of such practices in the Soviet Union, see J. INGLES, STLDY of Discrimination IN RESPECT OF THE RIGHTS OF EVERYoNe To LEAVE ANY COUNTRY, INCLUDING His OWN, AND To RETuRN To His CounTRY 25-29, U.N. Doc. E/CN.4/Sub.2/220/Rev.1 (1963); W. KOREY, THE SOVIET CAGE: ANTI-SEMITISM IN Rossia 184-200 (1973). See also V. ChaldDzE, supra note 8, at 92-114; A. SAKHAROV, MY COUNTRY AND THE WORID 51-61 (G. Daniels transl. 1975); A. SAKHarov, SakHaRov Speaks 159-63 (H. Salisbury ed. 1974); Shroeter, How They Left: Varieties of Soviet Jewish Exit Experience, 2 Soviet JewISH AFraIRS 9 (1972).

15. J. INGLES, supra note 14, at 28-29.

16. The methods employed have been said to include " $[t]$ he spy system, delation, secrecy, torture, the union in one person of judge and accuser, the hindrances put in the way of the victim's defence, the direct interest of the tribunal in a condemnation which secured the confiscation of the property of the accused." Fawkes, Persecution (Roman Catholic), 9 ENCYC. OF RELIGION AND ETHICs 749, 753 (J. Hastings ed. 1960). For a detailed case study, see H. KaMEN, The SPANISH INQUISITION 137-96 (1965).

17. See, e.g., Gwatkin, supra note 10 , at $742,746$.

18. See, e.g., Nelson, The Theory of Persecution, in Persecution AND LiberTy: ESSAYS IN HONOR OF GEORGE IINCOLN BURR 3 (1931) (Christian practices). See generally Labrousse, Religious Toleration, 4 DICTIONARY OF THE HISTORY OF IDEAS 112, 115 (P. Wiener ed. 1973).

19. Gwatkin, supra note 10 , at 747.

20. H. Santa CRuz, Study of Discrimination in the Matter of Political RIGHTS 34, U.N. Doc. E/CN.4/Sub.2/213/Rev.1 (1962).

21. Id.

22. Id. See also J. LAponce, The Protection of Minorimes 49-50 (1960). 
rather than "merit" and exclude from public service "members of religious communities not recognized by the State."

In the area of educational opportunities, individuals may find access to public education, or educational resources and facilities, restricted because of their religious backgrounds. Such deprivations cannot be dismissed as historic curiosities. According to a United Nations study, "qualified candidates in some parts of the world still find their religion a barrier when they apply for admission to certain educational institutions." "A4 "Although this discrimination is not overt and is in many cases contrary to the law," the study adds, "it nevertheless persists and affects a considerable number of persons."25 The intricate relationship between religion and education, especially in regard to religious instruction, may precipitate community tension and conflict. ${ }^{26}$ In addition, among the ubiquitous means of maintaining religious conformity are the policies designed to preserve an ignorant public and to stifle individual freedom of expression. Notorious examples of book burning abound in history. ${ }^{27}$ Limited access to the means of enlightenment often results in limited opportunities for the acquisition and exercise of socially useful skills.

In a community in which discrimination takes the form of persecution, severe deprivations of well-being may ensue, ranging from the imprisonment and torture of individuals to the physical extermination of entire populations (genocide). ${ }^{28}$ The barbarity of such depriva-

23. H. SANTA CRUZ, supra note 20, at 35. Difficult problems arise when an individual leaves a group in which religious process is the functional equivalent of civil process. See, e.g., Zaretsky, Jesus in Jerusalem 1973: Mission Impossible?, in HEBREW Ciristianity: THe THIRTEENTH TRIBE 341, 350-52 (B. Sobel ed. 1974). 24. C. Ammoun, Study of Discrimination in EDUCation 56, U.N. Doc. E/CN.4/Sub.2/181/Rev.1 (1957).

25. Id.

26. This is most visible in cases in which proselytization is used as a form of public information. See Zaretsky, supra note 23, at 383-85. Cf. L. DE CAMP, THE Great Monkey Trial (1968); Evolution and Religion: The Conflict BetWeEN SCIENCE AND THEOLOGY IN MODERN AMERICA (G. Kennedy ed. 1957); R. MORGAN, THE Politics of Religious CONFLICT (1968).

27. See, e.g., Gwatkin, supra note 10, at 747.

In a fashion less dramatic than book burning, the Nationalist Chinese government, in January 1975, confiscated some 2300 copies of Bibles in romanized Taiwanese (some of them in the Tayal tribal language) from the Protestant community in Taiwan. This much protested act in violation of religious freedom is another step in a series of governmental measures designed to ban the use of the Taiwanese language and to suppress the Taiwanese (non-Chinese) identity of the Taiwanese people. See The Washington Post, May 2, 1975, at C7, col. 4; The Confiscation of the Taiwanese Bibles by the Nationalist Chinese Government, 71 MAYFLOWER 7 (July 20, 1975) (published by the Formosan Club of America, Inc.); Joint Statement Concerning the Taiwanese Bibles, 176 Tarwan Chenglan 23 (June 1975) (published by World United Formosans for Independence); Tang, On the Incident of Confiscating the Taiwanese Bibles, 177 Tatwan Chenglian 34 (July 1975).

28. The Nazi Holocaust is a well-remembered example of such practices. See R. Hilberg, Destruction of the European Jews (1961); H. Krausnick, H. Buchheim, M. Broszhat \& H. Jacobsen, The Anatomy of the SS-State (1968); N. Levin, The Holocaust: The Destruction of the European Jewry (1968); R. 
tions has been vividly recorded: "[T] he extirpation of heresy by fetter and by fire";29 victims "worried by dogs, or crucified, or burned as lights for the performances" in emperor's gardens;, victims "left to die of famine in prison";31 issuance of edicts requiring "all persons," including "women and boys," to be sacrificed;32 "great massacre",;3 "public executions";34 "wholesale burnings";35 "the most terrible form of fire and slaughter";3 extermination "by sword, by hurling from the summits of cliffs, by prolonged confinement in deadly prisons, at the stake, in the mines";37 and survivors "sent in chains into slavery." 38

With regard to the right to acquire and dispose of property, an individual's religious identification not infrequently becomes a source of discrimination. Nonconformists may have their property confiscated, $^{30}$ groups who profess particular religious faiths may be forbidden the right to own land, ${ }^{40}$ public funds may be dispensed

Manyell \& H. Fraenkel, The Incomparable Crime (1967); L. Poliakov, Harvest of Hate (1954); G. Reitlinger, The Final Solution (2d ed. 1968); J. TenenBAUM, RACE AND ReICH (2d ed. 1956); Holocaust, 8 ENCYC. JUdAICA 827 (1971).

29. Labrousse, supra note 18 , at 115.

30. Gwatkin, supra note 10 , at 744 .

31. Id. at 746 .

32. Id.

33. Id. at 747 .

34. Id. at 748 .

35. Id.

36. Geden, Persecution (Indian), 9 ENCYC. OF RELIGION AND ETHICs 762, 764 (J. Hastings ed. 1960).

37. 2 T. LINDSAy, A History OF THE REFormation 601 (1907). Hence, this observation: "But the horrors enacted in open court are a very small part of the mischiefs of persecution. We must take account of imprisonments and hardships from which even death is sometimes a relief, and of the sufferings of those who live in fear of death or yield to fear of death. Worse than this is the brutalizing of the persecutors, and worst of all the demoralization of the persecuted." Gwatkin, supra note 10 , at 748 .

38. Gwatkin, supra note 10, at 747 .

Deprivations are sometimes inflicted by the victims themselves because of religious beliefs in the community. Such believers may deny themselves the benefits of modern medical treatment by relying on spiritual healing only, by refusing vaccination and physical examination, and by refusing blood transfusions. See generally $\mathrm{C}$. ANTIEAU, P. Carroll \& T. BURkE, RELIGION UNDER THE STATE CONSTITUTIONS 67-72 (1965); M. Cole, Jehovah's Witnesses (1955); D. Gross, The Case for SpIRitual Healing (1958); J. Van BaAlen, The Chaos of Cults (3d ed. 1960); Burkholder, "The Law Knows No Heresy": Marginal Religious Movements and the Courts, in Rezigrous Movement, supra note 2, at 27, 36-41; Garrison, Sectarianism and Psychosocial Adjustment: A Controlled Comparison of Puerto Rican Pentecostals and Catholics, in id. at 298-319; Pfeffer, The Legitimation of Marginal Religions in the United States, in id. at 9, 17-20; Torrey, Spiritualists and Shamans as Psychotherapists: An Account of Original Anthropological Sin, in id. at 330-37; Cawley, Criminal Liability in Faith Healing, 39 MINN. L. REv. 48 (1954); Note, The Refused Blood Transfusion: An Ultimate Challenge for Law and Morals, 10 NATURAL L.F. 202 (1965).

39. See, e.g., Gwatkin, supra note 10, at 747.

40. Such prohibition may take different forms: (1) only members of the state religion can own land; (2) no members of any religion may own land; and (3) 
in a manner that clearly discriminates against certain religious groups, ${ }^{41}$ and religious quotas may be imposed in employment. ${ }^{42}$ In the words of an International Labour Office (ILO) study:

The most numerous charges of discrimination would seem to relate to access to jobs in both the public service and the private sector. The acts of discrimination complained of appear to consist for the most part in the imposition of religious tests in selecting candidates for public appointments and the granting of preferences to members of particular faiths when engaging workers or taking on apprentices. However, discrimination may also occur in certain situations against people who belong to any religion at all, against atheists or against those who do not profess any faith whatever. ${ }^{43}$

Religious discrimination continues to have an important effect upon the shaping and sharing of the affection value. People of different religious backgrounds may be prohibited by legal or religious proscription from marrying one another. ${ }^{44}$ Violators may be subjected to severe legal penalties or to social opprobrium. On a more general level, religious barriers tend to stifle the growth of congenial personal relationships.

Finally, even in the most modern societies it is not always easy for people of different religions to share a sense of mutual respect. Religious antagonists have been "[1]ikened to the poisoner of wells, the arsonist, the counterfeiter, and the murderer-the heresiarch and the votaries whom he enticed were pictured as public pests which the authorities had the solemn obligation to purge from the face of the earth." 45 At one time, religious nonconformists were simply "reduced to slavery."48 Today, individuals may enjoy differing degrees of prestige because of differences in religious affiliations. Religion almost invariably figures significantly in the class structure of a community, especially where it is highly rigidified and hierarchical. ${ }^{47}$

members of some religions subjected to persecution may not own land. For instance, see the case of Emma Berger in Israel described in Zaretsky, supra note 23, at 388, 398 n.27.

41. See P. KaUper, Religion AND the Constitution 18-19 (1964); J. LAPONCE, supra note 22 , at 48 .

42. W. KOREY, supra note 14 , at 52 .

On occasion, discrimination in employment may be imposed against people who are religiously forbidden to work on those days when the employer wants them to work. See Burkholder, supra note 38, at 33-36; Pfeffer, supra note 38, at 17-20. 43. INTERNATIONAL LABour OFFICE, FIghting Discrimination IN EMPLOYMENT AND OCCUPATION 98 (1968).

44. See A. Krishaswami, supra note 1 , at 38; 3 A. Stokes, Church and State IN THE UNTTED STATES 52-56 (1950). Cf. Geden, supra note 36, at 764-65.

45. Labrousse, supra note 18 , at 115 .

46. See Gwatkin, supra note 10 , at 747.

47. See McDougal, Lasswell \& Chen, The Protection of Respect and Human Rights: Freedom of Choice and World Public Order, 24 AM. U. L. REv. 919, 983-84 (1975). See also T. O'DEA, The Sociology of ReLigion 55-97 (1966). 


\section{Bastc Community Policies}

In a community genuinely committed to the goal of human dignity, one paramount policy should be to honor and defend the freedom of the individual to choose a fundamental orientation toward the world. One of the most distinctive acts available to man as a rational being is the continual redefinition of the self in relation to others and to the cosmos. Thus, each individual must be free to search for the basic postulates in a perspective that will unify the experiences of life. All practices that both differentiate among individuals upon the basis of religious beliefs and expressions, whether conceived and justified in transempirical or empirical terms, and deprive the individual of the freedom to inquire and choose are wholly incompatible with preferred policy. ${ }^{48}$

Even so fundamental a freedom as that of religious inquiry, belief, and communication must, of course, be exercised and protected with due regard for the comparable rights of others and for the aggregate common interest in the preservation of all basic human rights. ${ }^{49}$ Whether a particular practice is an appropriate exercise of religious freedom or is an unreasonable invasion of the rights of others may occasionally present a difficult and delicate question for community choice. The rational procedure for guiding community choice about such questions in the area of religious freedom, as in the case of other rights, is the disciplined use of a contextual analysis that investigates and assays the consequences of available options; no prior definitional exercises, however elaborate, can eliminate the need for inquiry and choice in the social process. ${ }^{50}$

48. The arbitrariness of differentiations by generic reference to religion is evident in the difficulties of defining "religion." As with the notion of "race," specialists on religion as well as nonspecialists can hardly agree upon a commonly acceptable definition. What are the criteria of "religious" groups: birth, devotions by one or both parents, self-definition and proclamation, conversion, conversion by group, or something else? Labeling people on the basis of religion, as on the basis of race, is easily susceptible of abuse. See Hollingsworth, Constitutional Religious Protection: Antiquated Oddity or Vital Reality?, 34 Oно ST. L.J. 15 (1973); Zaretsky, supra note 23.

49. The presumption against discrimination upon grounds of religion is not intended to obscure the fact that a community may have a deep interest in the quality of the rectitude standard of its members. Some religious concepts may be highly inimical to a public order of human dignity. It may on occasion be necessary to distinguish between discrimination upon religious grounds and the maintenance of an appropriate system of rectitude. The formation and proselytization of religious movements that emphasize some conceptions of pacifism may, for instance, be regarded as inimical to community security in some contexts.

See, e.g., Marnell, Civil Disobedience and the Majority of One, in RELIGION AND THE PUBliC ORder 115 (D. Giannella ed. 1969). Cf., e.g., Casad, Compulsory Education and Individual Rights, in id. at 51; Coughlin, Values and the Constitution, in id. at 89.

50. See McDougal, Human Rights and World Public Order: Principles of Content and Procedure for Clarifying General Community Policy, 14 VA. J. INTL. L. 387 (1974); McDougal, Lasswell \& Chen, supra note 47, at 927-37, 1037. See also Mc- 
None of the arguments historically put forward to impugn the policy of religious toleration carry much weight in a complex and interactive world. Attempts have been made to justify intolerance on the ground that a single faith has unique access to revealed truth (a monopoly of truth), ${ }^{51}$ or that intolerance is necessary for the "salvation" of individuals who are outside the mainstream of religious belief. ${ }^{52}$ More secular and pragmatic arguments allege the necessity of achieving and maintaining community unity and cohesion against the perils of fragmentation into nonconformist groups. ${ }^{63}$ The specious nature of claims to a monopoly of truth or exclusive access to transempirical salvation would appear amply demonstrated by the failure of any of the diverse belief systems present in the contemporary world to establish unique or exclusive successes in either empiri-

Dougal, Lasswell \& Chen, The Aggregate Interest in Shared Respect and Human Rights: The Harmonization of Public Order and Civic Order (forthcoming).

In response to the conventional "action-belief" dichotomy for policy differentiation used in American jurisprudence, Kurland has emphasized that "this proposed distinction . . . [is] obviously not a line that can provide real assistance in resolving these knotty problems." P. KURLAND, Religion AND tHE LAW 22 (1962). Similarly, Burkholder observes:

If we ask just how the limits of religious freedom are set by the courts, it is clear that no one definitive rationale for adjudication has emerged. The jurists have developed a number of testing procedures-secular regulation, interest weighing, clear and present danger, compelling state interest, alternative means -but only the first of these offers a self-evident approach. In creating the possibility of carving out an exemption from existing legislation for certain kinds of religiously motivated action, and justifying this exemption by balancing religious conviction against public policy, the Sherbert formula tended to favor a case-by-case procedure. We have seen how court opinions may vary widely in their application of this balancing technique.

Burkholder, supra note 38 , at 45.

51. In his essay on Sir James MacKintosh, Macaulay described such views: "I am in the right, and you are in the wrong. When you are the stronger, you ought to tolerate me; for it is your duty to tolerate truth. But when I am stronger, I shall persecute you; for it is my duty to persecute error." T. MACAULAY, CRITICAL AND Historical Essays 336 (1870). Cf. N. SODERbLOM, THE LIVING God: Basal Forms of Personal Religion (1933); R. Zaehner, At Sundry Times (1958).

52. "[A] body of truths existed, some still latent, some explicitly stated in dogmas, necessary and vital; so vital that, unless a man accepted them, he would without doubt perish everlastingly ...." Whitley, supra note 13, at 755. Augustine is said to have compared "the laws against heretics to the restraint imposed upon lunatics or persons suffering under delirium, who would otherwise destroy themselves and others." Fawkes, supra note 16, at 751, 752. Cf. S. Brandon, History, Time AND DEITY (1965); S. BRANDON, MAN AND HIS DESTINY IN THE GREAT RELIGIONS (1962).

53. Labrousse has aptly summarized: "If one reflects upon it, one is struck by the coherence and doctrinal consistency of the ideological justifications provided for the practice of religious intolerance. The system of justification stands up admirably on all levels, and the unavoidable sociological necessity for a minimum consensus gives it an imperative accent. This necessity for consensus has not disappeared from among us . . . " Labrousse, supra note 18, at 115-16. A similar observation was offered by Fawkes: "Cohesion was the first need of primitive societies; it was more important that the group should cohere than it should progress. Innovation, therefore, was put down with a strong hand: it introduced disunion and dissipated energy-the argument is not unknown in our own time." Fawkes, supra note 16, at 749. 
cal or transempirical inquiry. ${ }^{54}$ Moreover, underlying all of the theories of religious intolerance is an assumption that is essentially contrary to respect for human dignity-an assumption that implies a profound distrust of the wisdom of allowing individuals to take the responsibility for their own beliefs. If human experience is a reliable guide, it would appear that individuals will not experience an intense demand on the self to act responsibly on behalf of the common interest unless they are free to pursue their own search to relate the ego to other beings and to the universal manifold of events. The attempt to impose uniformity in such fundamental matters stifles and frustrates personal development and fulfillment. Similarly, it would appear that, in the long run, social order and individual well-being can be better achieved through open examination and choice of fundamental orientations than through regimented religious monolithism. ${ }^{55}$

The importance of individual freedom of inquiry and commitment to community consensus about shaping and sharing of values has been aptly summarized by Abram:

Since that formative period of the concepts of religious liberty in the seventeenth century, differing justifications of the right to freedom of thought, conscience or belief have been advanced. Some, like Mill, have stressed the fallibility of human thought and belief; others, like Dewey, have argued the social benefits derivable from plurality of belief and freedom of inquiry; and others have calculated the comparative risks for social value of a policy of freedom, as opposed to the risks of repression. One conclusion from the number and variety of such justifications is that no single theological, secular or philosophical foundation is presupposed in the belief in the right to freedom of thought, conscience and religion. Defenders of the ideal and institutions of freedom do not and need not share metaphysical, theological or psychological beliefs; rather, they share a commitment to the

54. See generally W. ChRistian, MEANING aNd TRUTh IN REIIGION (1964); B. MTtChell, The Justification of Religious BeLIEF (1973).

55. The classic exposition of this policy is J. LOCKE, LetTers Concernnng TOLERATION (1765). In 1689, the year the Act of Toleration was proclaimed in England, Locke's first Letter was anonymously published in Holland in Latin and translated into English immediately afterward. Three other Letters soon followed, largely in response to criticism. Emphasizing that the legitimate sphere of the state extends to external matters rather than internal matters such as religion, Locke maintained that not only the basic doctrines and articles of faith, but also the outward manifestations and rites of worship are to be kept beyond the reach of the civil authority. Not only religious toleration but also disestablishment of religion was suggested.

See R. AARON, John LOCKe 24-25, 39-40, 52, $295-99$ (1937); J. DunN, The PolmTical Thought OF JoHN LOCKE 27-40 (1969).

For an excellent contemporary exposition of the policies favoring toleration, see P. Kauper, supra note 41, at 13-44. Cf. R. Bainton, The TravaIl of Religious LIBERTY (1951); S. Hook, REligion IN A FREe SOCIETY (1967); P. MilleR, ET AL,

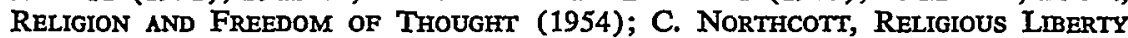
(1948); R. POLLARD, CONSCIENCE AND LibERTY (1940). 
value of freedom in the life of the community and an appreciation of the fruits of freedom for society and the individual. ${ }^{56}$

\section{Trends IN Decision}

The development of transnational principles of religious freedom begins within the body politic of national communities. Even within these communities, the journey toward religious tolerance has been slow and tortuous. "Ancient society," it has been noted, "was essentially intolerant." Th7 Though the concepts of religious toleration and religious freedom were articulated at relatively early stages in history, ${ }^{68}$ their transformation into national prescription and practice has been gradual. "Tolerance," observed Arcot Krishnaswami in his outstanding study, "was accorded, in the beginning, to one or a few specified religions or beliefs; and only later was it extended to all such groups. Moreover, the measure of tolerance extended to various groups was often very narrow at first, and only by a gradual expansion was full equality achieved." ${ }^{.95}$ Krishnaswami also noted that "[s]truggles for freedom of religion and conscience have occurred chiefly in Europe. For many historic non-European religions, which developed without having the feeling of possessing absolute and exclusive religious truth, the problem of toleration did not take so acute a form." 60

In Europe, the drive toward religious toleration became significant after the Protestant Reformation. ${ }^{61}$ The formal incorporation of the principle of religious toleration into national law first appeared in Switzerland and Transylvania, two relatively small multi-religious communities bordering the great empires. ${ }^{62}$ In Switzerland, under the Peaces of Kappel of 1529 and 1531, each canton was empowered to decide which faith, Reformed or Catholic, its inhabitants would observe. ${ }^{63}$ In the "common bailiwicks, ruled by Reformed and Cath-

\footnotetext{
56. Abram, supra note 1, at 44-45.
}

57. Gwatkin, supra note 10 , at 743 .

58. See Bainton, Sebastian Castellio and the Toleration Controversy of the Sixteenth Century, in PERSECUTION AND LIBERTY: ESSAYS IN HONOR OF GEOROR LINCOLN BuRR 183 (1931). Cf. M. BATES, supra note 1, at 378-473; D. BuRT, The State aNd Religious Toleration: Aspects of the Church-STATE Theories of Four ChristIAN THINRERS (1960); Bainton, The Parable of the Tares as the Proof Text for Religious Liberty to the End of the Sixteenth Century, 1 CHurch Hist. 67 (1932).

59. A. KRISHNASWAMr, supra note 1 , at 4 .

60. Quoted in Toth, supra note 1, at 208.

61. See generally R. Batnton, The Reformation of THE Sixteneth Century (1952); $M$. Bates, supra note 1 , at 148-86; O. Chadwick, The ReFormatton (1965); G. EltoN, ReFormation EuRoPe, 1517-1599 (1964); H. GrimM, THE ReFormation ERA, 1500-1650, at 588-92 (1954); T. LINDSAY, supra note 37; R. POST, ThE MODERN Devotion: Confrontation WITH ReFormation AND HuMaNism (1968); Bainton, The Struggle for Religious Liberty, 10 CHURCH HIST. 95 (1941).

62. Toth, supra note 1 , at 209.

63. A. Krisennaswami, supra note 1, at 4; Toth, supra note 1, at 209. 
olic cantons in common," adhere to their faith alongside the Protestant majority ${ }^{65}$ In the Principality of Transylvania (then part of the Kingdom of Hungary), individuals enjoyed freedom of conscience and religion as early as 1538 under a decree by the Diet of Torda, ${ }^{66}$ which was reaffirmed in 1571. In 1555, Germany officially justified freedom of religion in terms of "the will of the sovereignty," "the Raison d'état." France, after the religious wars of 1562 to 1598 , Henry IV issued the famous Ediot of Nantes, conferring upon the Calvinists (the Huguenots) specific civil liberties, including "the right to worship in specified places." In England, the Toleration Act of 1689 secured personal toleration for Protestants of all sorts, although Protestant dissenters from the Church of England still remained under certain disabilities. ${ }^{69}$

The French and American revolutions brought with them a shift in "emphasis from the principle of mere toleration under the aegis of enlightened despotism to that of a more effective freedom and equality of worship."70 The Declaration of the Rights of Man, issued in 1789 after the French Revolution, specified freedom of religious expression as within the scope of human rights entitled to protection: "No man is to be interfered with because of his opinions, not even because of religious opinions, provided his avowal of them does not disturb public order as established by law." "11 Many European immigrants who settled in the New World brought with them the growing expectation of religious freedom, and the principle of religious liberty gradually spread throughout the colonies. The Constitution of the United States prescribed, in article VI, that "no religious Test shall ever be required as a Qualification to any Office or public Trust under the United States." The first amendment, adopted in 1791, further stated that "Congress shall make no law respecting an establishment of religion or prohibiting the free exercise thereof." ${ }^{22}$ With

64. A. KRIShNaswam, supra note 1 , at 4 .

65. Id.; Toth, supra note 1 , at 209.

66. Toth, supra note 1 , at 209.

67. Id. This was based on the doctrine "cujus regio eius religio" embodied in the Treaty of Augsburg of 1555.

68. A. KRISHNASWAM, supra note 1, at 5. Unfortunately, the Edict of Nantes of 1598 was revoked in 1685 by Louis XIV, who ordered the destruction of the Calvinist temples and forbade Calvinists to leave the country.

69. M. BATES, supra note 1, at 168-79.

70. De Ruggiero, Religious Freedom, in 13 ENcyc. Soc. ScI. 239, 244 (E. Selgman \& A. Johnson eds. 1934).

71. BASIC DOCUMENTS ON HUMAN RIGHTS 9 (I. Brownlie ed. 1971).

72. This part of the first amendment contains both the establishment clause and the free-exercise clause. "The essence of the religious freedom guaranteed by our Constitution is therefore this: no religion shall either receive the state's support or incur its hostility." West Virginia Bd. of Educ. v. Barnette, 319 U.S. 624, 654 (1943) (Frankfurter, J., dissenting). Similarly, Konvitz has observed:

The Free Exercise Clause protects one against coercion to do what one does not 
the passage of time, this fundamental guarantee of religious freedom, building upon the principle of separation of church and state, has been amplified and strengthened by a series of judicial decisions. ${ }^{73}$

Influenced by the examples set by France and the United States, "[i]n the written constitutions of the nineteenth and twentieth centuries the guarantee of freedom of religion appears with impressive uniformity."74 In the Soviet Union, for example, shortly after the February Revolution of 1917, legal protection was accorded to freedom of conscience, "including the right to profess any religion or to profess none."75 Following the October Revolution, Lenin reaffirmed this right by proclaiming in January 1918, "the separation of the Church from the State and the School from the Church," thereby

believe or approve; the Establishment Clause protects one against coercion to do even what one would want to do voluntarily and what one would approve if it were done freely. Taken together, their purpose is not to degrade or weaken religion in any respect whatsoever, but, on the contrary, as with the other guarantees of the First Amendment, to recognize and to implement the belief that "Almighty God hath created the mind free"; and that man is not man unless his mind remains free; and that God is not served except by a mind that is free. Had God wanted a coerced worship, He would have created not man but an unfree agent; and what God did not choose to do, the government a fortiori may not do.

M. KONVITZ, EXPANDING LIBERTIES 29 (1966) (emphasis original).

73. In his recent study, Pfeffer observes that

on the whole the American people have been faithful to the commitment that, the business of God is not that of Caesar. This does not mean that there have been no deviations and lapses. Although the national Constitution contains no reference to God, practically every State Constitution does invoke His name (usually in the preamble) and acknowledges the people's dependence on Him. Christmas is a national holiday; legislatures, national and State, open their sessions with prayer; prayer meetings are sporadically held in the White House; "In

God We Trust" is to be found on the currency of the realm, and "under God" in our Pledge of Allegiance. These and similar instances of governmental religiosity are, however, marginal and of little significance.

L. Pfeffer, God, Caesar, and the Constitution 345-46 (i975).

On the general question of church and state in the United States, see S. ConB, The Rise of Religious LiberTy IN AMERICA (1902); T. EMERSON, D. HABer \& N. DORSEN, Political aNd CIvil RIGHTS IN THE UNITEd StaTes 736-854 (student ed. 1967); P. KAUPER, supra note 41; M. KonvITZ, supra note 72, at 3-47; M. Konviz, Religious LiberTy AND CoNSCIENCE (1968); P. KURLANd, supra note 50; W. MARNELl, THE FIRST AMENDMENT: THE History of Religious FreedoM IN AMERICA (1964); R. Morgan, The Supreme Court and Religion (1972); L. Pfeffer, Church, State and Freedom (rev. ed. 1967); B. Schwartz, Rights of the Person: EQUALITY, Belief AND Dignity $649-709$ (1968); A. Stokes, supra note 44; A. Stores \& L. PFeffer, Church and State in the United States (rev. ed. 1964); ToRPEy, Judicial Doctrines of Religious Rights IN AMERICA (1948); Bittker, Churches, Taxes and the Constitution, 78 YALE L.J. 1285 (1969); Burkholder, supra note 38; Hollingsworth, supra note 48; Kauper, The Supreme Court and the Establishment Clause: Back to Everson?, 25 CASE W. REs. L. REv. 107 (1974); Pfeffer, supra note 38; Pfeffer, Uneasy Trinity: Church, State, and Constitution, 2 Crv. Liberties REV., No. 1, at 138 (1975); Schwarz, No Imposition of Religion: The Establishment Clause Value, 77 Yale L.J. 692 (1968). Cf. J. Bennett, Christians and the STate (1958).

74. H. LaUterpacht, AN International Bill of the Rights of MaN 105 (1945). For a detailed account of those constitutional provisions for religious liberty, see M. Bates, supra note 1, at 504-41.

75. A. KRISHNASWAMI, supra note 1 , at 6. 
abolishing the dominance of the Orthodox Church prevailing under Czarist Russia and guaranteeing "the equality of all religions."76 More recently, inspired by the Universal Declaration of Human Rights and other related pronouncements, the constitutions of the newly independent states have prominently incorporated religious freedom and equality into the protected sphere of human rights. ${ }^{77}$

The trends toward religious freedom and equality within national communities have not been isolated events. They have influenced one another and, in so doing, have brought about transnational expectations of religious liberty that, in turn, have strengthened national practice. Building upon the doctrine of natural rights as a source of transnational authority, Hugo Grotius (and other prominent international lawyers after him) emphasized that, in the same sense that international law is important to the maintenance of religious toleration, is religious toleration indispensable to a stable international order. ${ }^{78}$ Thus, Krishnaswami noted that, "[e]ven before the concept of freedom of thought, conscience and religion was recognized in national law-and partly because it had not been so recognized-the practice evolved of making treaty stipulations ensuring certain rights to individuals or groups professing a religion or belief different from that of the majority in the country."70 In 1536, the King of France and the Ottoman Emperor concluded a treaty conferring various liberties, including freedom of religion, upon French subjects within the Ottoman territory; ${ }^{80}$ these stipulations in the form of "capitulations" in peace treaties "became the model for many later treaties of this sort as the capitulation system spread during the seventeenth, eighteenth and early nineteenth centuries."81 The Treaty of Westphalia, concluded in 1648 after the Thirty Years' War, represented an important step toward ensuring toleration both for Protestants in Catholic states and for Catholics in Protestant states, although it fell short of affording religious freedom to all individuals and groups. ${ }^{82}$ Another landmark was the Treaty of Berlin of 1878, pursuant to which the newly established states of Bulgaria, Montenegro, Romania, Serbia, and the Sublime Porte (the Ottoman Empire) undertook to ensure religious freedom to all their inhabi-

76. Id. Cf. H. LAUTERPACHT, supra note 74, at 106.

77. Cf. A. Carrillo de Albornoz, Religious Liberty 160-62 (J. Drury transl. 1967); RELIGIOUS FREEDOM (Councilium. vol. 18, 1966).

78. R. Bantion, supra note 61 , at 16-17. Cf. M. Manton, Religious Prohibitions UNDER the Mexican Constitution Before the League of Nations aNd the Permanent Court of International Justice 12-28 (1934); R. Higgins, CoNFLICT OF INTERESTS: INTERNATIONAL LAW IN A DIVIDED WORLD 17-22 (1965).

79. A. KRISHNASWAMr, supra note 1 , at 11 .

80. See id.; Toth, supra note 1 , at 210.

81. A. KRISHNASWAMI, supra note 1 , at 11.

82. Id. See also C. Eckhardt, The Papacy and World Affairs: As Reflected in the Secularization of Politics (1937). 
tants. ${ }^{83}$ Thus, in regard to Bulgaria, the Treaty provided in article 5:

The difference of religious creeds and confessions shall not be alleged against any person as a ground for exclusion or incapacity in matters relating to the enjoyment of civil and political rights, admission to public employments, functions, and honours, or the exercise of the various professions and industries in any locality whatsoever.

...

The freedom and outward exercise of all forms of worship are assured to all persons belonging to Bulgaria, as well as to foreigners, and no hindrance shall be offered either to the hierarchical organization of the different communions, or to their relations with their spiritual chiefs. ${ }^{84}$

Similar provisions were incorporated in article 27 (regarding Montenegro), ${ }^{85}$ article 35 (regarding Serbia), ${ }^{86}$ and article 44 (regarding Romania). ${ }^{87}$ Additional obligations were imposed upon the Ottoman Empire in article 62:

All persons shall be admitted, without distinction of religion, to give evidence before the tribunals;

Ecclesiastics, pilgrims, and monks of all nationalities travelling in Turkey in Europe, or in Turkey in Asia, shall enjoy the same rights, advantages, and privileges . . . .

The right of official protection by the Diplomatic and Consular Agents of the Powers in Turkey is recognized both as regards the above-mentioned persons and their religious, charitable, and other establishments in the Holy Places and elsewhere... . .

The monks of Mount Athos, of whatever country they may be natives, shall be maintained in their former possessions and advantages, and shall enjoy, without exception, complete equality of rights and prerogatives. ${ }^{88}$

Those peace treaties containing provisions regarding religious freedom, from 1648 (Westphalia) to 1878 (Berlin), shared an overriding concern: the protection of religious minorities by guaranteeing freedom of conscience and religion. ${ }^{89}$ It was this same concern that inspired the early development of the doctrines and practices of humanitarian intervention in customary international law. In the words of Ganji:

The history of international protection of Minorities to the early part of the 20th Century is that of the international protection of religious Minorities. If not all, the greater part of the history of humanitarian intervention is the history of intervention on behalf of per-

83. The text of the Treaty of Berlin, signed on July 13,1878, is reprinted in 2

Kex Treaties For the Great Powers 1814-1914, at 551-77 (M. Hurst ed. 1972).

84. Id. at $555-56$.

85. Id. at 564 .

86. Id. at 567 .

87. Id. at 570-71.

88. Id. at 575 .

89. See M. BATES, supra note 1 , at $477-84$. 
secuted religious minorities. These interventions were as a rule initiated by states whose people were linked by ties of religious belief to the persecuted minorities of the state intervened against. As far back as the latter part of the 17th Century there is, in the history of international relations, evidence of international protection of religious minorities undertaken by the European Powers. ${ }^{90}$

In addition to inserting provisos into peace treaties, states have often inserted provisions guaranteeing religious freedom into bilateral treaties of amity, commerce, and navigation. ${ }^{91}$ This type of protection was particularly favored by Great Britain and the United States. For example, in order to ensure religious freedom for Americans abroad, the United States included such protective clauses in the treaties of friendship and commerce with The Netherlands (1782), with Sweden (1783), and with Prussia (1785) ${ }^{92}$ Article 9 of the treaty with Prussia stipulated: "The most perfect freedom of conscience and of worship is granted to the citizens or subjects of either party within the jurisdiction of the other, without being liable to molestation in that respect for any other cause than an insult on the religion of others." ${ }^{\text {93 }}$ Comparable protection against religious discrimination was provided for in the bilateral treaties concluded by the United States with, respectively, China, Japan, Siam, the Congo, Germany, Ecuador, Honduras, Austria, Norway, Poland, Finland, Liberia, and Iraq. ${ }^{94}$ The protection offered by these treaties was "reciprocal" and extensive, providing for "freedom of public worship, with due reservation of proper requirements, for foreigners to enjoy the same rights and benefits as nationals, including residence, travel, and the right to hold property for religious purposes, with express or implied right to conduct religious, educational, and philanthropic work."95

Transnational efforts toward eliminating religious discrimination were fortified with the establishment of the League of Nations. The Covenant of the League, in article 22(5), held a Mandatory "responsible for the administration of the territory under conditions which will guarantee freedom of conscience and religion."96 Thus,

90. M. Ganji, International Protection of Human Rights 17 (1962) (footnote omitted). For further details, see $i d$. at 17-44.

91. See M. Bates, supra note 1 , at 477-87, 542-43; R. WiLson, UnIted States COMMERCIAL TREATIES AND INTERNATIONAL LAW 244-79 (1960).

92. M. BATES, supra note 1 , at 485 .

93. Quoted in id. at $485-86$.

94. Id. at 479,486 .

95. Id. at 486. Cf. R. HigGINs, supra note 78, at 23-39.

96. The mandate system of the League was designed, at the end of World War $I$, to detach the territories of the defeated powers (i.e., Turkish territories and the German colonies in Africa and Oceania) and to entrust them to mandatory powers. For further details and subsequent development, see N. BeNTwich, THE MaNDates SYSTEM (1930); R. CHOWDHUR,, INTERNATIONAL MANDATES AND TRUSTEESHIP SYstems (1955); League of Nations, The Mandate System (1945); A. Margalith, 
article 1 of the French Mandate for Togoland (or the Cameroons) (Class B) stipulated:

The Mandatory shall ensure in the territory complete freedom of conscience and the free exercise of all forms of worship, which are consonant with public order and morality; missionarics who are nationals of States Members of the League of Nations shall be free to enter the territory and to travel and reside therein, to acquire and possess property, to erect religious buildings, and to open schools throughout the territory; it being understood, however, that the Mandatory shall have the right to exercise such control as may be necessary for the maintenance of public order and good government, and to take all measures required for such control. ${ }^{97}$

Similarly, the South African Mandate for South-West Africa (Class C) provided:

Subject to the provisions of any local law for the maintenance of public order and public morals, the Mandatory shall ensure in the territory freedom of conscience and the free exercise of all forms of worship, and shall allow all missionaries, nationals of any State Member of the League of Nations, to enter into, travel and reside in the territory for the purpose of prosecuting their calling. ${ }^{08}$

Further important efforts to advance the goal of religious freedom were made under League auspices through the international regime of minority protection. Religious minorities were among the minority groups that the League of Nations was empowered to protect. ${ }^{00}$ In post-World War I arrangements (effected through both treaty stipulations and League resolutions), designed by the League to shelter minority groups from discrimination and oppression, a profound concern was manifested for religious freedom. The Treaty with Poland, signed at Versailles on June $28,1919,{ }^{100}$ served as a prototype for comparable arrangements with a number of other states including Czechoslovakia, the Serb-Croat-Slovene State, Romania, Greece, Austria, Bulgaria, Hungary, and Turkey (through treaty

The International Mandates (1930); J. Murray, The United Nations TrusteuSHIP SYSTEM (1957); 1 L. OPPENHEIM, INTERNATIONAL LAW 212-42 (8th ed. H. Lauterpacht 1955); L. SoHn \& T. Buergenthal, InTERnational Protrction of Human RIghts 337-504 (1973); C. Toussaint, The TRusteeship OF THE UNITED Nations (1956); E. Van Mannen-Helmer, The Mandates System in Relation to AFRICA AND THE PACIFIC ISLANDS (1929); Q. WRIGHT, MANDATES UNDER THE LEAGUE OF NATIONS (1930). See generally Chen, Self-Determination as a Human Right, in TOWARD WORLD ORDER AND HUMAN DIGNITY (W. Reisman \& B. Weston eds. forthcoming).

97. Quoted in Bates, supra note 1, at 488.

98. Reprinted in Basic Documents on International Protection of Human RIGHTS 242, 244 (L. Sohn \& T. Buergenthal eds. 1973) [hereinafter BAsIC DocUMENTS] (art. 5).

99. See McDougal, Lasswell \& Chen, supra note 47, at 1054-56.

100. Reprinted in League of Nations, Protection of Lingutstic, Racial aNd Religious Minorities by the League of Nations, 1927 I.B. 2, at 41-45. 
stipulation) and Albania, Esthonia, Latvia, Lithuania, and Iraq (through League resolutions). ${ }^{101}$

A close examination of the provisions of the treaty with Poland documents the deep demand existing at that time for protection against religious discrimination. Article 2 of the treaty obliged Poland to "assure full and complete protection of life and liberty" to all of its inhabitants "without distinction" as to "religion" or other factors. ${ }^{102}$ The same article afforded more general protection: "All inhabitants of Poland shall be entitled to the free exercise, whether public or private, of any creed, religion, or belief, whose practices are not inconsistent with public order or public morals." nationals," according to article 7, "shall be equal before the law and shall enjoy the same civil and political rights without distinction as to race, language or religion." 104 "Differences of religion, creed or confession," the article added, "shall not prejudice any Polish national in matters relating to the enjoyment of civil or political rights, as for instance admission to public employments, functions and honours, or the exercise of professions and industries."105 Finally, article 8 provided:

Polish nationals who belong to racial, religious or linguistic minorities shall enjoy the same treatment and security in law and in fact as the other Polish nationals. In particular they shall have an equal right to establish, manage and control at their own expense charitable, religious educational establishments, with the right to use their own language and to exercise their religion freely therein. ${ }^{106}$

All of these provisions were recognized under article 1 , as "fundamental laws" and, hence, the treaty stipulated that "no law, regulation or official action shall conflict or interfere with these stipulations, nor shall any law, regulation or official action prevail over them."107 Furthermore, these duties were, pursuant to article 12, made "obligations of international concern" and placed "under the guarantee of the League of Nations." 108

The contemporary proscription against religious discrimination, like comparable proscriptions concerning race and sex, ${ }^{109}$ is firmly established in the Charter of the United Nations and has been further amplified in related human rights instruments. In the Charter provi-

101. See id.

102. Id. at 43.

103. Id.

104. $I d$.

105. Id. When people are deprived of the opportunity to become nationals because of religious beliefs, however, such a provision is futile.

106. Id. at 44.

107. Id. at 42 .

108. Id. at 44 .

109. See McDougal, Lasswell \& Chen, supra note 47, at 1042-86; McDougal, Lasswell \& Chen, Human Rights for Women and World Public Order: The Outlawing of Sex-Based Discrimination, 69 AM. J. INTL. L. 497 (1975). 
sions concerning discrimination, religion is consistently specified, along with race, sex, and language, as an impermissible ground of differentiation..$^{110}$ At the San Francisco Conference of 1945, it was proposed (notably by Latin American delegations) that detailed guarantees of freedom of conscience and religion be incorporated in the Charter; however, these proposals were not accepted.111 Instead, by repeatedly employing the familiar formula of "human rights and fundamental freedoms for all, without distinction as to race, sex, language or religion,"112 the Charter established a more general norm prohibiting discrimination. This policy was first implemented in the post-World War II peace treaties concluded in 1947 by the Allied Powers with Bulgaria, Finland, Hungary, Italy, and Romania. Each state pledged to undertake "all measures necessary to secure to all persons under [its] jurisdiction, without distinction as to race, sex, language or religion, the enjoyment of human rights and of the fundamental freedoms, including freedom . . . of religious worship. ...."113

In attempting to explicate the Charter's comprehensive prohibition of discrimination, the Universal Declaration of Human Rights, in article 2, specifies religion as among the impermissible grounds of differentiation. ${ }^{114}$ This general prohibition of discrimination is made more explicit in article 18:

Everyone has the right to freedom of thought, conscience and religion; this right includes freedom to change his religion or belief, and freedom, either alone or in community with others and in public or private, to manifest his religion or belief in teaching, practice, worship or observance. ${ }^{115}$

Article 1, by proclaiming that all human beings are "endowed with reason and conscience and should act towards one another in a spirit of brotherhood," explore and define a personal orientation toward other persons and the universe. In order to implement this aspiration, article 26(2)

110. U.N. ChARTER art. 1, para. 3; art. 13, para 1(b); art. 55(c); art. 62, para. 2; art. $76(\mathrm{c})$.

111. A. Krishnaswam, supra note 1 , at 12 .

112. See Charter provisions cited in note 110 supra.

113. Treaty of Peace with Bulgaria, Feb. 10, 1947, art 2, No. 643, 41 U.N.T.S. 21; Treaty of Peace with Hungary, Feb. 10, 1947, art. 2, No. 644, 41 U.N.T.S. 135; Treaty of Peace with Romania, Feb. 10, 1947, art. 3, No. 645, 42 U.N.T.S. 3; Trenty of Peace with Finland, Feb. 10, 1947, art. 6, No. 746, 48 U.N.T.S. 203. See also Treaty of Peace with Italy, Feb. 10, 1947, art. 19(4), No. 747, 49 U.N.T.S. 3 (with a slight variation in wording from the preceding provisions).

114. G.A. Resolution 217A(III), U.N. GAOR pt. 1, U.N. Doc. A/810 (1948), reprinted in UNITED NATIONS, HUMAN RIGHTS: A COMPILATION OF INTERNATIONAL INSTRUMENTS OF THE UNITED NATIONS 1, U.N. Doc. ST/HR/1 (1973) [hereinafter U.N. HUMAN RIGHTS INSTRUMENTS].

115. Id.

116. Id.

117. Id. 
urges that education be directed to "promote understanding, tolerance and friendship among all nations, racial or religious groups."117

Important protection for religious groups can also be found in a number of relatively recent conventions, including the Genocide Convention of 1948. ${ }^{118}$ This convention seeks "to prevent and to punish" certain acts "committed with intent to destroy, in whole or in part," religious groups, among others; the acts prohibited include "killing members of the group," causing members of a protected group "serious bodily or mental harm," deliberate infliction of living conditions calculated to bring about group destruction, "measures intended to prevent births within the group," and forcible transfer of children. ${ }^{119}$ The convention also punishes "conspiracy," "incitement," "attempt to commit," and "complicity in genocide."120 Both the Convention relating to the Status of Refugees (1951) and the Convention relating to the Status of Stateless Persons (1954) protect refugees and stateless persons from religious discrimination and accord them "national treatment" with regard to "freedom to practice their religion and freedom as regards the religious education of their children." "21 The Discrimination (Employment and Occupation). Convention of 1958, which aspires to bring about "equality of opportunity of treatment in employment or occupation," includes religion among the prohibited grounds of differentiation. ${ }^{122}$ Similarly, the Convention against Discrimination in Education of 1960, designed to ensure "equality of opportunity and treatment for all in education," specifically prohibits discrimination on the basis of religion. ${ }^{123}$

In the International Covenant on Civil and Political Rights, adopted by the General Assembly in 1966 (taking effect on March 23 , 1976), religion is included in both the general provision against discrimination in the enjoyment of all human rights under article

118. Convention on the Prevention and Punishment of the Crime of Genocide, opened for signature Dec. 9, 1948, No. 1021, 78 U.N.T.S. 277, reprinted in U.N. HUMAN RIGHTS INSTRUMENTS, supra note 114, at 41.

119. Id.

120. Id.

121. Article 3 provides that "[ $t]$ he Contracting States shall apply the provisions of this Convention to refugees without discrimination as to race, religion or country of origin," and article 4 reads: "The Contracting States shall accord to refugees within their territories treatment at least as favourable as that accorded to their nationals with respect to freedom to practice their religion and freedom as regards the religious education of their children." Convention relating to the Status of Stateless Persons, Sept. 9, 1954, No. 5158, 360 U.N.T.S. 130, reprinted in U.N. HUMAN RIGHTS INSTRUMENTS, supra note 114, at 61 . Comparable provisions are found in articles 3 and 4 of the Convention relating to the Status of Refugees, July 28, 1951, No. 254, 189 U.N.T.S. 150, reprinted in U.N. HUMAN RIGHTS INSTRUMENTS, supra, at 68.

122. Convention concerning Discrimination in respect to Employment and Occupation, June 25, 1958, No. 5181, 362 U.N.T.S. 31, reprinted in U.N. HUMAN RIGHTS INSTRUMENTS, supra note 114, at 29.

123. Dec. 14, 1960, No. 6193, 429 U.N.T.S. 93, reprinted in U.N. HUMAN Rughts INSTRUMENTS, supra note 114 , at 31 . 
$2(1)^{124}$ and in the equal protection clause under article $26{ }^{125}$ The prohibition of discrimination is regarded as of such overriding importance that states are forbidden to practice discrimination on the ground of religion (or on the ground of race, color, sex, language, or social origin) where derogations from their obligations would otherwise be justified by "public emergency" under article 4(1). ${ }^{120}$ In article $18(1)$, the basic content of the right so emphatically protected is defined by prescribing complete freedom of choice regarding rectitude: "Everyone shall have the right to freedom of thought, conscience and religion. This right shall include freedom to have or to adopt a religion or belief of his choice, and freedom, either individually or in community with others and in public or private, to manifest his religion or belief in worship, observance, practice and teaching."127 Article 18(2) further insulates this right by providing protection against coercion that would "impair" an individual's "freedom to have or to adopt a religion or belief of his choice."128 Article 18(3) then expresses the recognition that this freedom, like other rights, is subject to the necessity of appropriate accommodation with the aggregate common interest. ${ }^{128}$ In addition, article 24(1) provides that the special protection accorded to children is to be effected without discrimination on account of religion, ${ }^{130}$ and article 27 specifically includes religious minorities among the protected minority groups. ${ }^{131}$

Similarly, the International Covenant on Economic, Social, and Cultural Rights (adopted by the General Assembly in 1966 and

124. G.A. Res. 2200, 21 U.N. GAOR Supp. 16, at 52, U.N. Doc. A/6316 (1966), reprinted in U.N. HUMAN RIGHTS INSTRUMENTS, supra note 114, at 8.

125. $I d$.

126. Article $4(1)$ of the International Covenant on Civil and Political Rights reads:

In time of public emergency which threatens the life of the nation and the existence of which is officially proclaimed, the States Parties to the present Covenant may take measures derogating from their obligations under the present Covenant to the extent strictly required by the exigencies of the situation, provided that such measures are not inconsistent with their other obligations under international law and do not involve discrimination solely on the ground of race, colour, Id. sex, language, religion or social origin.

127. Id.

128. $I d$.

129. Article 18(3) reads: "Freedom to manifest one's religion or beliefs may be subject only to such limitations as are prescribed by law and are necessary to protect public safety, order, health, or morals or the fundamental rights and freedoms of others." Id.

130. Article 24(1) provides: "Every child shall have, without any discrimination as to race, colour, sex, language, religion, national or social origin, property or birth, the right to such measures of protection as are required by his status as a minor, on the part of his family, society and the State." Id.

131. Article 27 stipulates: "In those States in which ethnic, religious or linguistic minorities exist, persons belonging to such minorities shall not be denied the right, in community with the other members of their group, to enjoy their own culture, to profess and practice their own religion, or to use their own language." Id. 
becoming operative on January 3,1976 ) contains, in article 2(2), a comprehensive guarantee that the rights stipulated in the covenant will be exercised without discrimination on the ground of religion. ${ }^{132}$ Article 13(1) amplifies this guarantee by proclaiming that education be directed to "enable all persons to participate effectively in a free society, promote understanding, tolerance and friendship among all nations and all racial, ethnic or religious groups."133 It may be recalled, finally, that the Proclamation of Teheran of 1968 insists that it is "imperative that the members of the international community fulfill their solemn obligations to promote and encourage respect for human rights and fundamental freedoms for all without distinctions of any kind," including "religion."134

Both the continuing demand for more tightly articulated international prescriptions to ensure religious freedom and the difficulty involved in formulating such prescriptions are demonstrated by the efforts within the United Nations to formulate a convention and a declaration on elimination of all forms of religious intolerance. At its seventeenth session in 1962, the General Assembly (in response to recurring manifestations of anti-Semitism and other forms of racial and religious prejudice) decided to formulate a declaration and a convention on "the elimination of all forms of religious intolerance," paralleling a set of instruments on "the elimination of all forms of racial discrimination."135 Although the Declaration and the Convention on the Elimination of All Forms of Racial Discrimination were successively adopted by the General Assembly in 1963 and in 1965 (the latter taking effect on January 4, 1969), ${ }^{136}$ the contemplated declaration and convention on the elimination of religious intolerance are yet to be completed. This "marked contrast," characterized by "the stormy course of the instruments dealing with religious intolerance,"137 has been caused by a coalition of delegations seeking to downplay the issues of anti-Semitism and other forms of religious intolerance. ${ }^{138}$ Religious warfare, it would appear, is not entirely an

132. G.A. Res. 2200, 21 U.N. GAOR Supp. 16, at 49, U.N. Doc. A/6316 (1966), reprinted in U.N. HUMAN RIGHTS INSTRUMENTS, supra note 114, at 3.

133. $I d$.

134. U.N. Doc. A/CONF. $32 / 41$ (1968), reprinted in U.N. HUMAN RIGHTS INSTRUMENTS, supra note 114 , at 18 .

135. See McDougal, Lasswell \& Chen, supra note 47, at 1058-60.

136. Id.

137. Liskofsky, Eliminating Intolerance and Discrimination Based on Religion or Belief: The U.N. Role, REPORTS ON THE FOREIGN SCENE, Feb. 1968, No. 8, at 1, 3. 138. See McDougal, Lasswell \& Chen, supra note 47, at 1058-60. See also Liskofsky, supra note 137 , at 3-4.

For the legislative history of the proposed declaration and the proposed convention on the elimination of religious intolerance and discrimination, see Manifestations of Racial Prejudice and National and Religious Intolerance (Report of the SecretaryGeneral), U.N. Doc. A/6347 (1966); Elimination of All Forms of Religious Intolerance (Note by the Secretary-General), U.N. Doc. A/7177 (1968); Elimination of All Forms of Religious Intolerance (Note by the Secretary-General), U.N. Doc. A/7930 
affair of the past. In 1964 (two years after the Assembly's decision to formulate a declaration and a convention), the Sub-Commission on Prevention of Discrimination and Protection of Minorities submitted a preliminary draft declaration ${ }^{139}$ to the Commission on Human Rights, which, through a fifteen-member Working Group, was able to agree only upon six of the proposed articles. ${ }^{140}$ After reporting this outcome to the Assembly through the Economic and Social Council and seeking further instructions, ${ }^{141}$ the Commission began preparing a draft convention.

In 1965, the Sub-Commission presented a preliminary draft convention to the Commission. ${ }^{142}$ Building upon the Sub-Commission's draft, the Commission, at its sessions from 1965 to 1967, adopted a preamble and twelve articles but was unable to consider the proposed articles on measures of implementation. ${ }^{143}$ The Commission's draft convention, together with other related proposals not considered by the Commission, was transmitted to the General Assembly in 1967 by the Economic and Social Council; the Council also expressed the hope that the Assembly would decide on appropriate implementation provisions. ${ }^{144}$ The Assembly considered the draft convention at its twenty-second session in 1967 and decided to change its title to draft International Convention on the Elimination of All Forms of Intolerance and of Discrimination based on Religion or Belief; ${ }^{146}$ however, since the 1967 session, the Assembly has deferred consideration of the draft convention.

In December 1972, the Assembly decided to "accord priority to the completion of the Declaration on the Elimination of All Forms of

(1970); Elimination of All Forms of Religious Intolerance (Note by the SecretaryGeneral), U.N. Doc. A/8330 (1971) [hereinafter U.N. Doc. A/8330]; Elimination of All Forms of Religious Intolerance (Report of the Third Committee), U.N. Doc. A 9322 (1973); Draft Declaration on the Elimination of All Forms of Religious Intolerance (Working Paper prepared by the Secretariat), U.N. Doc. E/CN.4/1145 (1973).

139. Commission on Human Rights, Report on the TWEntieth SEssion, 37 U.N. ECOSOC, Supp. 8, at 69-74, U.N. Doc. E/3873 (E/CN.4/874) (1964). The full text of the preliminary draft of a "United Nations Declaration on the Elimination of All Forms of Religious Intolerance, Prepared by the Sub-Commission on Prevention of Discriminaiton and Protection of Minorities" [hereinafter Sub-Commission Draft Declaration] is conveniently attached as an annex to U.N. Doc. A/8330, supra note 138.

140. Commission on Human Rights, supra note 139, at 74-81; U.N. Doc. A/8330, supra note 138 , at 4 . The text of the articles as prepared by the Working Group [hereinafter Working Group Draft Declaration] is attached as an annex, to U.N. Doc. A/8330, supra.

141. U.N. Doc. A/8330, supra note 138 , at $4-5$.

142. Id. at 5. The draft convention [hereinafter Commission Draft Convention] is also attached as an annex to U.N. Doc. $\mathrm{A} / 8330$.

143. Id. at 6.

144. ECOSOC Res. 1233, 42 U.N. ECOSOC, Supp. 1, at 13, U.N. Doc. E/4393

(1967).

145. U.N. Doc. A/8330, supra note 138 , at 7. 
Religious Intolerance before resuming consideration of the International Convention on this subject."148 The Assembly instructed that the drafts previously prepared in 1964 by the Sub-Commission and the Working Group of the Commission on Human Rights be circulated to member states and specialized agencies for comments. ${ }^{147}$ It further urged "the adoption, if possible, of such a Declaration as part of the observance of the twenty-fifth anniversary of the Universal Declaration of Human Rights" in 1973. ${ }^{148}$ Yet, in 1973, the task remained unfinished and its consideration took a new turn. While reaffirming the priority accorded to the "completion of the Declaration," in December of 1973, the Assembly indicated that "the preparation of a draft Declaration" required "additional study." Accordingly, it instructed the Commission on Human Rights to "submit, if possible, a single draft Declaration to the Assembly at its twenty-ninth session" in 1974 in the light of the suggestions, comments, and amendments recently received. ${ }^{149}$ The Commission was, however, nowhere near the completion of its newly assigned task at its thirtieth and thirty-first sessions held in 1974 and $1975 .^{150}$ In view of the slow progress within the Commission, it is unclear when the draft declaration will be completed and adopted by the General Assembly; moreover, completion of the draft convention appears to be even a more remote possibility.

Despite the delay in their completion and adoption, the contours of the proposed declaration and the proposed convention have been

146. G. A. Res. 3027,27 U.N. GAOR, Supp. 30, at 72, U.N. Doc. A/8730 (1972).

147. Id.

148. Id.

149. G. A. Res. 3069, 28 U.N. GAOR, Supp. 30, at 77-78, U.N. Doc. A/9030 (1973). See also G. A. Res. 3267, 29 U.N. GAOR, Supp. 31, at 88-89, U.N. Doc. A/9631 (1975); Elimination of All Forms of Religious Intolerance (Report of the Third Committee), U.N. Doc. A/9893 (1974).

For recent comments by various governments, see Draft Declaration on the Elimination of All Forms of Religious Intolerance (Report of the Secretary General), U.N. Doc. A/9134 (1973); Analytical presentation of the observations received from Governments concerning the draft Declaration on the Elimination of All Forms of Religious Intolerance (Note by the Secretary-General), U.N. Doc. A/9135 (1973); Draft Declaration on the Elimination of All Forms of Religious Intolerance (Report of the Secretary-General), U.N. Doc. E/CN.4/1146 (1974).

150. Commission on Human Rights, Report on the Thirtieth Session (4 Feb.-8 March 1974), 56 U.N. ECOSOC Supp. 5, at 7, 18-22, 57, U.N. Doc. E/5464 (E/CN.4/1154) (1974). After considerable debate in its Thirtieth Session in 1974 about ways and means of accelerating the preparation of a single draft declaration, the Commission has set up "an informal Working Group open to all members of the Commission." Id. at 19. The informal Working Group, with Mr. Pierre Juvigny (France) serving as Chairman-Rapporteur, agreed to proceed on the basis of "consensus," and was able to consider only "the title and the first two preambular paragraphs of a draft Declaration" in the six meetings it held in February 1974.

For an account of the limited progress made in 1975, see Commission on Human Rights, Report on the Thirty-First Session (3 Feb.-7 March 1975), 58 U.N. ECOSOC Supp. 4, at 4, 36-41, U.N. Doc. E/5635 (E/CN.4/1179) (1975). 
sufficiently articulated in the available drafts to make it possible to anticipate their ultimate form. Taken together, the respective drafts of the declaration proposed by the Sub-Commission ${ }^{151}$ and the Working Group of the Commission on Human Rights, ${ }^{152}$ along with the draft convention prepared by the Commission, ${ }^{153}$ appear to parallel the Declaration and the Convention on the Elimination of Racial Discrimination. This parallelism is observable in proposed provisions concerning the grounds of differentiation prohibited, the rights protected, the specific acts forbidden, and the actors precluded from engaging in discrimination. ${ }^{154}$

Discrimination on the ground of religion or belief is condemned as an "offence to human dignity," "a denial of the principles of the Charter of the United Nations," "a violation of the human rights and fundamental freedoms proclaimed in the Universal Declaration of Human Rights," and "an obstacle to friendly and peaceful relations among nations." "155 In terms as broad and inclusive as those used in the racial convention, the draft convention defines "discrimination on the ground of religion or belief" to mean "any distinction, exclusion, restriction or preference based on religion or belief which has the purpose or effect of nullifying or impairing the recognition, enjoyment or exercise, on an equal footing, of human rights and fundamental freedoms in the political, economic, social, cultural, or any other field of public life."156 The terms "religion or belief" are defined as including "theistic, non-theistic, and atheistic beliefs."157 In recognition of the "complexities of the issues involved in the elaboration of standards for religious liberty in a world community of diverse beliefs and institutions,"158 article 1(4) of the draft convention adds: "Neither the establishment of a religion nor the recognition of a religion or belief by a State nor the separation of Church from State shall by itself be considered religious intolerance or discrimination on the ground of religion or belief." ${ }^{60}$ This provision appears to be an unfortunate departure from the conventional wisdom that the establishment or recognition of an official religion may promote intolerance of other beliefs. ${ }^{160}$

151. Sub-Commission Draft Declaration, supra note 139.

152. Working Group Draft Declaration, supra note 140.

153. Commission Draft Convention, supra note 142.

154. See McDougal, Lasswell \& Chen, supra note 47, at 1060-72.

155. Sub-Commission Draft Declaration, supra note 139 , art. 1 , at 2 ; Working Group Draft Declaration, supra note 140, art. 2, at 2.

156. Commission Draft Convention, supra note 142, art. 1(b), at 2.

157. Commission Draft Convention, supra note 142, art. 1(a).

158. Abram, supra note 1 , at 46.

159. Commission Draft Convention, supra note 142, art. 1(d), at 2.

160. In the words of Krishnaswami:

For centuries. a close relationship existed in almost all countries between the State and the predominant religion. This religion enjoyed a special status, either because it had been recognized as the Established Church or because it had been 
The drafts of both the convention and the declaration contemplate comprehensive protection against religious discrimination. Thus, the drafts speak in terms of protecting all of the "political, civic, economic, social and cultural rights"101 and "human rights and fundamental freedoms" in "any other field of public life."162 In the course of considering which rights should be protected by the proposed instruments, however, a fundamental issue has been "whether to deal only with discrimination based on religion or belief, e.g. in employment, education, housing or citizenship, or, in addition, with the 'freedom' of all to practice and manifest religion and belief."163 The response has thus far been in favor of the latter position; this position appears to recognize that, in order to eliminate religious intolerance and discrimination, it is essential to "keep fully in the forefront the substance of the right to freedom of thought, conscience and religion."104 "What would be the meaning of tolerance," it has been asked, "without the affirmation of the rich substance of the right, which all should be free to exercise?"165 Hence, both the draft declaration and the draft convention make elaborate and detailed provision for "the right to freedom of thought, conscience, religion or belief" as the core freedom, indispensable to the achievement of an environment free from discrimination on account of religion or belief. This core freedom, to be extended to everyone, includes:

(1) Freedom to adhere or not to adhere to any religion or belief and to change his religion or belief in accordance with the dictates of his conscience....

accepted as the State religion. Not infrequently recognition of the predominant religion led to the total exclusion of all other religions, or at least to their reduction to a subordinate position. Thus in the past the mere existence in a country of an Established Church or of a State religion usually connoted severe discrimination-and sometimes even outright persecution-directed against dissenters.

A. KRISHNASWAMI, supra note 1 , at 46 . Commenting on this conventional wisdom, he cautioned readers today not to jump to such an inference without a thorough contextual scrutiny. Id. at 46-54.

In the same vein, Abram has explained:

Member States include those in which there is complete separation of Church and State, those in which several religions are recognized by the State, and those with a single Established Church or State religion. While it has often been argued that a particular juridical relationship logically determines a potential pattern of infringement of the rights of minority religions or beliefs, it seems difficult to confirm this argument in practice. . . .

The moral of these examples is easily drawn: the determinants of the religious freedom of a society include not only the juridical framework and the laws of the State but also the mores of the society, including the value placed upon this freedom by the major religions and ideologies within the society.

Abram, supra note 1 , at $46-47$.

161. Commission Draft Convention, supra note 142 , art. 5 , at 4 . See also

Working Group Draft Declaration, supra note 140, art. 4(1), at 2.

162. Commission Draft Convention, supra note 142, art. 1(b), at 2.

163. Liskofsky, supra note 137 , at 3 .

164. Observations made by the Commission of the Churches on International Affairs to the Sub-Commission's Draft Declaration, reprinted in A. Carrillo DE AlBORNOZ, RELIGIOUS LIBERTY 32, 33 (1964).

165. Id. 
(2) Freedom to manifest his religion or belief either alone or in community with others, and in public or in private . . . .

(3) Freedom to express opinion on questions concerning a religion or belief.

(4) Freedom to worship, to hold assemblies related to religion or belief....

(5) Freedom to teach, to disseminate and to learn his religion or belief . . . .

(6) Freedom to practise his religion or belief by establishing and maintaining charitable and educational institutions . . . .

(7) Freedom to observe the rituals, dietary and other practices of his religion or belief . . . .

(8) Freedom to make pilgrimages and other journeys in connection with his religion or belief. . . .

(9) Equal legal protection for the places of worship or assembly, the rites, ceremonies and activities, and the places of disposal of the dead associated with his religion or belief;

(10) Freedom to organize and maintain local, regional, national and international associations in connexion with his religion or belief. . . .

(11) Freedom from compulsion to take an oath of a religious nature. ${ }^{166}$

The particular acts that would be prohibited by the draft convention and the draft declaration include "any distinction, exclusion, restriction or preference" that "has the purpose or effect of nullifying or impairing" equality in "recognition, enjoyment or exercise" of protected rights. ${ }^{167}$ The fourfold characterizations of "distinction, exclusion, restriction or preference" are sufficiently broad to encompass a wide range of activities. ${ }^{168}$ In addition, criminal sanctions would be imposed for "[a]ny act of violence against the adherents of any religion or belief or against the means used for its practice, any incitement to such acts or incitement to hatred likely to result in acts of violence against any religion or belief or its adherents,"160 and "all propaganda designed to foster or justify" such activities. ${ }^{170}$

166. Commission Draft Convention, supra note 142, art. 3, at 2-3. See also SubCommission Draft Declaration, supra note 139, art. 6, at 3-4; Working Group Draft Declaration, supra note 140 , art. 6 , at 3 .

A further protection concerns the right of parents or legal guardians to bring up their children in the religion or belief of their choice and their responsibility to inculcate in their children tolerance for the religion of others. States would further be obliged not to discriminate "in the granting of subsidies, in taxation or in exemptions from taxation, between different religions or beliefs or their adherents." Sub-Commission Draft Declaration, supra note 139, arts. 5, 12, at 2, 4. See also Working Group Draft Declaration, supra note 140, art. 5, at 3; Commission Draft Convention, supra note 142 , art 4 , at 3-4.

167. Commission Draft Convention, supra note 142, art. 1(b), at 2.

168. See McDougal, Lasswell \& Chen, supra note 47, at 1068-71.

169. Commission Draft Convention, supra note 142, art. 9, at 5.

170. Sub-Commisssion Draft Declaration, supra note 139, art. 14(2), at 5. 
In their efforts to secure the elimination of religious intolerance and discrimination, the proposed drafts would, like the Declaration and the Convention on the Elimination of Racial Discrimination, bring both official and nonofficial actors within their authority: "No States, institution, group or individual" would be permitted to "make any discrimination in matters of human rights and fundainental freedoms in the treatment of persons on the grounds of their religion or their belief."171 These drafts also underscore the critical importance of intra-national action to bring about the necessary internal changes in both authoritative and effective power processes that would ensure the maintenance of the freedoms sought to be promoted by the drafts. ${ }^{172}$ The drafts manifest, finally, a deep realization of the necessity of an appropriate accommodation of the rights and freedoms to be enjoyed by individuals with the aggregate common interest. ${ }^{173}$

171. Id. art. 2, at 2. See also Working Group Draft Declaration, supra note 140, art. $3(1)$, at 2 .

172. Commission Draft Convention, supra note 142, art. 6, provides:

States Parties undertake to adopt immediate and effective measures, particularly in the fields of teaching, education, culture and information, with a view to combating prejudices as, for example, anti-Semitism and other manifestations which lead to religious intolerance and to discrimination on the ground of religion or belief, and to promoting and encouraging, in the interest of universal peace, understanding, tolerance, co-operation and friendship among nations, groups and individuals, irrespective of differences in religion or belief, in accordance with the purposes and principles of the Charter of the United Nations, the Universal Declaration of Human Rights and this Convention.

Article 7 would oblige contracting states to

take effective measures to prevent and eliminate discrimination on the ground of religion or belief, including the enactment or abrogation of laws of regulations where necessary to prohibit such discrimination by any person, group or organization, [and not to] pursue any policy or enact or retain laws or regulations restricting or impeding freedom of conscience, religion or belief or the free and open exercise thereof, nor discriminate against any person, group or organization on account of membership or non-membership in, practice or non-practice of, or adherence or non-adherence to any religion or belief.

Moreover, article 10 reads:

State Parties shall ensure to everyone within their jurisdiction effective protection and remedies, through the competent national tribunals and other State institutions, against any acts, including acts of discrimination on the ground of religion or belief, which violate his human rights and fundamental freedoms contrary to this Convention, as well as the right to seek from such tribunals just and adequate reparation or satisfaction for any damage suffered as a result of such acts.

See also Sub-Commission Draft Declaration, supra note 139 , arts. $3(2), 14$, at 2,5 ;

Working Group Draft Declaration, supra note 140, arts. 3(2), at 2.

173. The Commission Draft Convention, supra note 142, provides:

11. Nothing in this Convention shall be interpreted as giving to any person, group, organization or institution the right to engage in activities aimed at prejudicing national security, friendly relations between nations or the purposes and principles of the United Nations.

12. Nothing in this Convention shall be construed to preclude a State Party from prescribing by law such limitations as are necessary to protect public safety, order, health or moral or the individual rights and freedoms of others, or the general welfare in a democratic society.

Article 13(2) of the Sub-Commission Draft Declaration, supra note 139, reads:

The freedoms and rights set out elsewhere in this Declaration shall be subject only to the restrictions prescribed by law solely for the purpose of securing due 
On the regional level, the principle of religious freedom is embodied both in general prescriptions banning discrimination that include religion as a prohibited ground of differentiation and in more particular prescriptions that give substance to the freedom of thought, conscience, and religion. Thus, the European Convention on Human Rights includes religion, in article 14, as among the impermissible grounds of differentiation ${ }^{\mathbf{1 7 4}}$ and spells out the content of freedom of religion in article 9.175 Similarly, the American Declaration of the Rights and Duties of $\mathrm{Man}^{178}$ proclaims, in anticle 2, that "[a]11 persons are equal before the law and have the rights and duties established in this Declaration, without distinction as to race, sex, language, creed or any other factor." Article 1(1) of the American Convention on Human Rights ${ }^{177}$ expressly forbids discrimination on account of religion, and this general principle is reinforced by the equal protection clause of article 24; furthermore, article 27(1) provides that a state may not take measures that involve religious discrimination, even during a national emergency. The provision on the freedom of thought, conscience, and religion is found in article 12, which (like article 9 of the European Convention) employs wording essentially similar to that contained in article 18 of the Universal Declaration and of the International Covenant on Civil and Political Rights. ${ }^{178}$

In addition to the prescriptions emanating from secular sources, it is relevant to note that the fundamental philosophy of the world's great religions has increasingly exhibited support (including fewer demands for religious exclusivity and intolerance) for the principle of freedom of choice about religion. ${ }^{179}$ The principle of religious tolerance and freedom has become so deeply ingrained, both in the secular and nonsecular worlds, that a number of the great religions have recently issued manifestos in favor of religious freedom. The thrust of this new global movement is powerfully demonstrated by the Declaration on Religious Freedom, adopted by the Vatican II Council

recognition and respect for the rights and freedoms of others and of meeting the legitimate requirements of morality, health, public order and the general welfare in a democratic society. Any restrictions which may be imposed shall be consistent with the purposes and principles of the United Nations and with the rights and freedoms stated in the Universal Declaration of Human Rights. These freedoms and rights may in no case be exercised contrary to the purposes and principles of the United Nations.

174. Convention for the Protection of Human Rights and Fundamental Freedoms,

Nov. 4, 1950, reprinted in BASIC DocumenTs, supra note 98, at 125.

175. Id.

176. Reprinted in BAsic Documents, supra note 98, at 187.

177. Reprinted in id. at 210.

178. See text at notes $115,127-29$ supra.

179. See A. Carrillo de Albornoz, supra note 77; L. JANSSENS, Freedom op CONSCIENCE AND RELIGIOUS FREEDOM (Lorenzo transl. 1966); RELIGIOUS FreEDOM, supra note 77. Cf. Toth, The Churches and the New World Order, 11 WorsD JUSTICE 193 (1969). 
in $1965 .^{180}$ Inspired in no small measure by the Universal Declaration of Human Rights, this declaration pronounces that "the human person has a right to religious freedom,"181 which "has its foundation in the very dignity of the human person as this dignity is known through the revealed word of God and by reason itself."182 Elaborating on this freedom, the declaration states that "all men are to be immune from coercion on the part of individuals or of social groups and of any human power, in such ways that no one is to be forced to act in a manner contrary to his own beliefs, whether privately or publicly, whether alone or in association with others, within due limits."183 With this declaration - "an effort of the Church to catch up with the recognition of a right previously asserted in secular, protestant, Jewish and other religious traditions"184 - it has been observed that "for the first time in many centuries, Christians are unanimous in formally proclaiming the universality and inviolability of religious freedom. They all agree that it is the right of every man and every religious confession."185 A comparable trend is also observable in the non-Christian world. As Abram has put it, "In Judaism, in Islam, in Marxism, and in other religious or secular movements, there have been formulated claims of ultimate truth and of the special status that truth entails both for the believer and the non-believer, on the one hand, and arguments for the freedom of thought, conscience and religion of all men, on the other."186

The application of proscriptions against religious discrimination is, of course, still left to the more general enforcement machinery presently available for the protection of other human rights at varying

180. Reprinted in L. JANSSENS, supra note 179, at 145-60 and in A. CARRILIO DE Albornoz, supra note 77, at 169-87. See also A. Carrillo DE Albornoz, The Basis OF RELIGIOUS LIBERTY (1963); FREEDOM AND MAN (J. Murray ed. 1965); RELIGIOUS LIBERTY: AN END AND A BEgINNING (J. Murray ed. 1966).

181. A. CARRILlo DE AlborNoz, supra note 77 , at 170 ; L. JANSSENS, supra note 179 , at 146.

182. A. CARRILlo dE AlboRNoz, supra note 77, at 171; L. JANSSENS, supra note 179 , at 147.

183. A. CARRILIo DE Albornoz, supra note 77, at 170-71; I. JANSSENS, supra note 179 , at $146-47$.

184. Abram, supra note 1 , at $45-46$.

185. A. Carrillo DE Albornoz, supra note 77, at 155. For the Declarations on Religious Liberty issued by the World Council of Churches in 1948 and 1961, see id. at 189-99. The 1948 Declaration pronounced at the outset: "The rights of religious freedom herein declared shall be recognized and observed for all persons without distinction as to race, colour, sex, language, or religion, and without imposition of disabilities by virtue of legal provision of administrative acts." Id. at 189-90. It then proceeded to declare that "Every person" has "the right" to "determine his own faith and creed," to "express his religious beliefs in worship, teaching and practice, and to proclaim the implications of his beliefs for relationships in a social or political community," and to "associate with others and to organize with them for religious purposes." Id. at 190-91. Cf. P. Wogaman, Protestant Faith aNd Religious LIBERTY (1967).

186. Abram, supra note 1, at 45. Cf. Judarsm and Human Rights (M. Konvitz ed. 1972). 
community levels-national, regional, and global. ${ }^{187}$ It is to be hoped that the proposed International Convention on the Elimination of All Forms of Intolerance and of Discrimination Based on Religion or Belief, when finally adopted, will incorporate provisions for implementation comparable to those built into the International Convention on the Elimination of All Forms of Racial Discrimination. ${ }^{188}$ Meanwhile, it may be noted that, because discriminatory practices are sometimes based upon racial as well as religious grounds (such as practices conventionally labeled "anti-Semitism"), the machinery of implementation established for racial discrimination (especially the implementation provisions of the Convention on the Elimination of Racial Discrimination) can sometimes be invoked to redress deprivations based upon religious grounds. ${ }^{189}$

187. The general problem of implementation will be treated in detail in the chapters of our forthcoming book relating to the world constitutive process of authoritative decision.

188. Cf. McDougal, Lasswell \& Chen, supra note 47, at 1080-86. See Preliminary Draft on Additional Measures of Implementation Transmitted to the Commission on Human Rights by the Sub-Commission on Prevention of Discrimination and Protection of Minorities, annexed to U.N. Doc. A/8330, supra note 139. See also Claydon, supra note 1 , at 419-23.

189. With regard to many homogeneous groups it is difficult to tell whether characterizations of the group are by religion, ethnicity, or language (e.g., the Ibo, Dinka, or Zulu). This applies in both developing and developed countries. For such groups, protection of freedom from discrimination upon religious grounds may on occasion be secured by invocation and application of the prescriptions relating to race or language. Cf. Coleman, The Problem of Anti-Semitism Under the International Convention on the Elimination of All Forms of Racial Discrimination, 2 HumaN RIGHTS J. 609 (1969); Lerner, Anti-Semitism as Racial and Religious Discrimination Under United Nations Conventions, 1 ISRAEL Y.B. ON HuMaN Rughts 103 (1971); McDougal, Lasswell \& Chen, supra note 47, at 1061-86.

The ambiguities of religious and racial discrimination and other confusions are hopelessly intermingled in the controversial resolution on Zionism adopted by the United Nations General Assembly on Nov. 10, 1975, by a roll-call vote of 72 in favor, 35 against, with 32 abstentions. G. A. Res. 3379 (XXX), Resolutions of the General Assembly at Its Thirtieth Regular Session (16 Sept.-17 Dec. 1975), at 177, U.N. Press Release GA/5438 (19 Dec. 1975); 12 U.N. Monthly Chronicte, No. 11 , at 56 (1975). This resolution would appear more a gambit in a series of political maneuvers than an effective condemnation, or expression, of either racial or religious discrimination. For a review of the history and possible consequences of this resolution, see The Sixth Report of the Committee on Human Rights, the American Branch, International Law Association (March 1976) (to be published in 1976 Annual of the American Branch). See also Assembly Determines Zionism Is Form of Racism as Measures Against Racial Discrimination Adopted, 12 U.N. MONTHLY Chrontcle, No. 11, at 37 (1975); El-Messiri, Zionism and Racism, N.Y. Times, Nov. 13, at 41, col. 2 (city ed.); Glazer, Zionism Examined, id. Dec. 13, 1975, at 27, col. 3; id. Nov. 11, 1975, at 1, col. 1 .

For background readings on Zionism, see S. AHLsTROM, supra note 73, at $972-76$ (1972); I. Cohen, The Zionist Movement (1945); From Haven to Conquest: Readings in Zionsim and the Palestine Problem Untm 1948 (W. el-Khalidi ed. 1971); J. GONEN, A PSYCHOHITORY OF ZIONISM (1975); S. HALPERIN, THE Political World of American Zionism (1961); B. Halpern, The Idea of THE Jewish State (2d ed. 1969); The Zionist IDEA: A Historical ANalysis and REAder (A. Hertzberg ed. 1959); T. HerzL, The Jewish State (DER JUdenSTAAT) (H. Zohn transi. 1970); W. LAQUEUR, A History OF ZIONISM (1972); 2 B. MARTIN, A HiSTORY 


\section{The Inclusive Context of Religious and Other BASIC Freedoms OF BeLIEF}

The trend of past decision in the world community regarding matters of fundamental belief has been largely confined to the task of formulating acceptable prescriptions. Thus, the world community has yet to reach a consensus as to a system of presumptively authoritative expectations that can be invoked or applied in the area of religious discrimination. Nevertheless, it appears that the rising volume of national decisions implementing national prescriptions will one day be recognized as the preliminary phase of a process that marks the eventual appearance and consolidation of an effective international law of human rights in matters of religious conviction.

The intensified demands manifested in the drafting of declarations and conventions have already exercised a profound effect upon the perceived policies of the emerging system of world public order. It is, for example, more widely understood than ever before that "religious" freedom is not ultimately to be construed as faith in any particular version of divinity. The confrontations that have taken place between spokesmen for believers in a single God and spokesmen for believers in a plurality of gods have educated many of these leaders to concede the good faith and the depth of commitment of all concerned. A similar confrontation has had a parallel effect among exponents of divinity and "atheistic" champions of an impersonal flow of determining forces in the universe. Even more striking, perhaps, is the partial acceptance of "doubters" or "searchers"- those who have chosen to withhold commitment to any theological or metaphysical body of doctrine and practice. The scientific attitude toward the world, for example, is widely interpreted to exclude other than an exploratory and tentative attitude toward the universe.

For the future it is not implausible to predict that science-based technology will continue to spread, and that the tension between tentative versus dogmatic attitudes will become one of the most polarizing forces within the world community. The conception of religious freedom will probably come to be understood to include "freedom of fundamental orientation" toward the universal manifold of events; however, considerations of political unity may be expected to interfere with the genuine acceptance of this idea. When the unity of a body politic seems to be endangered by minorities of Christians, Jews, or adherents of other religious faiths, or by those who openly profess an "atheistic" or "agnostic" position, it will often be a simple

OF JUDAISM 319-48 (1974); O. RABINOWICZ, ARNOLD TOYNBEE ON JUDAISM AND ZIONISM: A CRITIQUe (1974); R. STEVENS, AMERICAN ZIONISM aND U.S. ForeigN Policy, 1942-1947 (1962); J. TALMON, IsRael AMong the Nations (1970); PAIestine: A SeArch For TruTH (A. Taylor \& R. Tetlie eds. 1970); D. VITAL, The ORIGINS OF ZIONISM (1975). 
matter to single out and identify members of these groups. During crisis periods, discriminatory measures will often be leveled against those perceived as dissident individuals and groups. If the level of crisis intensifies, it is overwhelmingly probable that the demand for political unity will tend to rigidify the position of whatever systems of belief are current among the power elites.

Under circumstances of fear and anxiety, it is well known that words and emblems may be among the instruments most relied upon to maintain a tolerable level of reassurance; conversely, exposure to assertions of disbelief or doubt, or to gestures of rejection, present occasions for symbolic defense. The demand to conform typically goes beyond insistence on verbal conformity; the proper words must also be uttered in tones that are recognized modes of expressing conviction. "Tentativeness" arouses suspicions of disloyalty or treason, and the range of tolerance afforded to variety and deviation is narrowed by both public and private acts.

Thus, it can be seen that the difficulties that have retarded the evolution of a comprehensive code of rights to protect freedom of religion and belief are likely to continue for the foreseeable future. Nevertheless, arrangements designed to extend and maintain the basic freedom to worship and to choose a belief system will continue to influence the differences and apprehensions that divide the members of the world community from one another. Freedom of belief is a tenacious yet delicate achievement in the history of mankind. 